\title{
一般 16
}

\section{上皮細胞における尿酸の paracellular 輸送}

目 的

上皮細胞における有機溶質やイオンの輸送ルー 卜は大きく分けて 2 つに分類される，1つは，上 皮細胞を横切って輸送される transcellularルート であり，トランスポーターやチャネルを介する輸 送である。もう1つが細胞と細胞の間を通る paracellularルートである. 本研究では, 数種類 の上皮由来細胞を用いた尿酸の paracellular輸送 について検討を行った。

\section{方 法}

胎盤絨毛上皮細胞由来としてBeWo, JEG-3 細 胞, 腎臓由来細胞として MDCK, LLC-PK 1 細胞, 腸管由来細胞として Caco-2 細胞を用いた. トラ ンスウェル上に細胞をコンフルエントになるまで 培養し, タイトジャンクションの形成を transepithelial electrical resistance (TER) と分 子量 3000 の蛍光デキストランの透過性で確認を 行った. タイトジャンクションの形成確認後, ト ランスポーターの働かない $4{ }^{\circ} \mathrm{C}$ 条件下で放射ラベ ルされた尿酸の輸送実験を行い，それぞれの細胞 における paracellular 輸送を観察した.
木村 徹 ${ }^{1)}$, 塚田 愛 ${ }^{2,3)}$, 市田 公美 ${ }^{2)}$,

櫻井 裕之 ${ }^{1)}$

\section{結果・考察}

使用したすべての細胞は，尿酸をほとんど細胞 内に取り込まなかった。これらの細胞をトランス ウェル上に培養すると, TERの上昇が観察され ただけでなく, 分子量 3000 の蛍光デキストラン を上部に添加しても，下部にほとんど透過しな かった. よって，これらの細胞は夕イトジャンク ションを形成していることが確認できた。この条

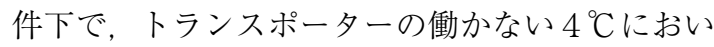
て，トランスウェル上下間での尿酸輸送を観察し た。その結果, 腎臓由来の MDCK, LLC-PK1細胞 では尿酸をほとんど通過させなかったが, 胎盤由 来の BeWo 細胞と JEG- 3 細胞では $4{ }^{\circ} \mathrm{C} て ゙ も$ 尿酸 の上下間での輸送が観察され, paracellular経路 で尿酸が輸送されていると示唆された。腸管由来 のCaco- 2 細胞は, 尿酸をよく輸送する細胞種と, ほとんど透過させない細胞種があり，そのサブタ イプによると考えている。この結果, 尿酸は, 腎 臓では transcellular 経路, 胎盤では paracellular 経路で運ばれ，腸管では両者が混在している可能 性が示唆された。
1 ) 杏林大学医学部薬理学教室

2 ) 東京薬科大学薬学部病態生理学教室

3 ) 東京都立大塚病院薬剂科
Toru Kimura, Hiroyuki Sakurai

Ai Tsukada, Kimiyoshi Ichida,

Ai Tsukada, 